\title{
CASOS DE RAIVA ANIMAL NOTIFICADOS NO ESTADO DE SÃO PAULO, 2014
}

\author{
NOTIFIED CASES OF ANIMAL RABIES IN THE STATE OF SÃO PAULO, 2014
}

\author{
E. M. N. PAULA ${ }^{1}$, C. A. CRUZ ${ }^{2}$, C. S. L. NOGUEIRA ${ }^{2} *$, R. B. MEIRELLES-BARTOLI ${ }^{1}$, \\ A. A. B. CARVALHO ${ }^{2}$
}

\section{RESUMO}

A raiva é uma zoonose viral que se caracteriza por encefalite progressiva aguda e letal. Os mamíferos são suscetíveis ao vírus da raiva e depois de infectados tornam-se fontes de infecção. A doença apresenta três ciclos de transmissão: urbano, silvestre, e rural. É interessante notar que nos três ciclos há a participação de morcegos hematófagos ou não para a transmissão da enfermidade. Devido ao quadro de destaque ocupado pela raiva, e a preocupação com a saúde pública, o objetivo desse estudo foi demonstrar o número de casos notificados de raiva em diferentes espécies animais no Estado de São Paulo. Este foi um trabalho descritivo, em que utilizou-se dados do ano de 2014, obtidos por meio de um levantamento realizado no sistema de informação da Secretaria de Vigilância em Saúde (SVS) do Ministério da Saúde. Entre janeiro e dezembro de 2014 foram notificados dois casos de cães positivos na cidade de Ribeirão Preto, no Estado de São Paulo. Avariante viral caracterizada neste caso foi a AgV3, que é compatível com morcego hematófago. Além disso, no município de Campinas, também no estado de São Paulo, foi notificado o caso de um gato (Felis catus) infectado pelo vírus da raiva com variante viral compatível com a do morcego não hematófago Nyctinomops sp. Além destes casos, foram infectados pelo vírus da raiva 180 bovinos, 32 equinos, três morcegos hematófagos, 41 morcegos não hematófagos, e oito animais de produção não especificados, todos reagentes aos testes realizados pelos laboratórios de referência.

Em relação aos outros estados brasileiros, São Paulo destaca-se por apresentar mais casos de raiva diagnosticados, entretanto, não podemos afirmar que a prevalência nesse Estado seja maior, uma vez que o que se nota é a subnotificação de diversas enfermidades, inclusive da raiva, em todo território nacional.

PALAVRAS-CHAVE: CICLO. MORCEGO. NOTIFICAÇÃO. ZOONOSE.

ÁREA TEMÁTICA: Zoonoses

\footnotetext{
${ }^{1}$ Universidade Federal de Goiás (UFG), Regional Jataí, Unidade Jatobá, Laboratório de Sanidade Animal ${ }^{2}$ Faculdade de Ciências Agrárias e Veterinárias da Universidade Estadual Paulista (UNESP) - Câmpus de Jaboticabal

* carolnogueira.vet@gmail.com
} 